\title{
PENDEKATAN PREFERENSI HABITAT DALAM PENYUSUNAN STRATEGI KONSERVASI IN SITU KAKATUA SUMBA (Cacatua sulphurea citrinocristata, Fraser 1844)

\author{
(Habitat Preferences Approach in Determining In-situ Conservation Strategy of Sumba \\ Cockatoo (Cacatua sulphurea citrinocristata, Fraser 1844))
}

\section{Oki Hidayat dan/and Kayat}

Balai Penelitian dan Pengembangan Lingkungan Hidup dan Kehutanan Kupang

Jl. Alfons Nisnoni No. 7 (Belakang), Airnona, Kota Raja, Kupang, NTT, Indonesia, Telp. (0380) 823357

\begin{tabular}{|c|c|}
\hline Info artikel: & ABSTRACT \\
\hline $\begin{array}{l}\text { Keywords: } \\
\text { Preference, } \\
\text { habitat, } \\
\text { conservation, } \\
\text { in situ, } \\
\text { sumba cockatoo }\end{array}$ & $\begin{array}{l}\text { Sumba cockatoo (Cacatua sulphurea citrinocristata, Fraser 1844) is an endemic fauna to } \\
\text { Sumba Island that critically endangered. Conservation efforts based on an ecological } \\
\text { approach is needed to preserve it. This study aimed to determine habitat preferences and } \\
\text { in-situ conservation strategies for Sumba cockatoos in the Maunupeu Tanadaru area, } \\
\text { Matalawa National Park. Observations were made in four forest blocks. Exploration was } \\
\text { carried out to determine the existence of Sumba cockatoos by the Look and See method. } \\
\text { Habitat preference analysis was performed using the Neu method. The results showed that } \\
\text { Sumba cockatoos preferred habitats that have an altitude range of } 401-600 \text { meters above } \\
\text { sea level, and slope level of steep slope (41-55\%), sloping (3-8\%) and very steep (> 55\%). } \\
\text { The most preferred location was in the Kokur Forest Block. Based on the results, in-situ } \\
\text { conservation strategies that can be carried out including: (1) Safeguarding nest trees from } \\
\text { natural and human threats; (2) Cleaning strangler figs and lianas on trees that are } \\
\text { important to cockatoos; (3) Enrichment of essential plants for cockatoos by planting } \\
\text { saplings. The results of this study are expected to be useful as a referencefor area managers } \\
\text { in determining in-situ conservation strategies through habitat development using the } \\
\text { habitat preference approach. }\end{array}$ \\
\hline
\end{tabular}

Kata kunci:

Preferensi,

habitat,

konservasi,

in-situ,

kakatua sumba

Riwayat artikel: Tanggal diterima: 08 April 2020; Tanggal direvisi: 04 Agutus 2020; Tanggal disetujui: 10 Agustus 2020

\begin{abstract}
ABSTRAK
Kakatua sumba (Cacatua sulphurea citrinocristata, Fraser 1844) merupakan satwa endemik Pulau Sumba yang terancam punah. Untuk melestarikannya, diperlukan upaya konservasi yang disusun berdasarkan pendekatan ekologis. Penelitian ini bertujuan untuk mengetahui preferensi habitat serta menentukan strategi konservasi in-situ kakatua sumba di kawasan Maunupeu Tanadaru, Taman Nasional Matalawa.-Pengamatan dilakukan di empat blok hutan. Penjelajahan dilakukan untuk mengetahui keberadaan kakatua sumba dengan metode Look and See. Analisis preferensi habitat dilakukan dengan menggunakan metode $\mathrm{Neu}$. Hasil penelitian menunjukkan bahwa kakatua sumba menyukai habitat yang memiliki ketinggian $401-600$ mdpl, kelerengan terjal $(41-55 \%)$, landai $(3-8 \%)$ dan sangat terjal (> $55 \%$ ). Lokasi yang paling disukai terdapat di Blok Hutan Kokur. Strategi konservasi in situ yang dapat dilakukan antara lain: (1) Pengamanan terhadap pohon sarang dari ancaman alam dan manusia; (2) Pembersihan ara pencekik dan liana pada pohon penting bagi kakatua; dan (3) Pengayaan tumbuhan penting bagi kakatua melalui penanaman anakan pohon. Hasil penelitian ini dapat digunakan sebagai acuan bagi pengelola kawasan dalam menentukan strategi konservasi in situ melalui pembinaan habitat dengan pendekatan preferensi habitat.
\end{abstract}

Editor: Ir. Reny Sawitri, M.Sc

Korespondensi penulis: Oki Hidayat ${ }^{\star}$ (E-mail: biokupang@gmail.com)

Kontribusi penulis: $\mathbf{O H}$ : Merancang dan melaksanakan penelitian, menyusun dan menulis karya tulis; K: Mengambil data di lapangan. 


\section{PENDAHULUAN}

Kakatua sumba (Cacatua sulphurea citrinocristata, Fraser 1844) merupakan salah satu subspesies Kakatua-kecil Jambul-kuning endemik Pulau Sumba yang berstatus kritis terancam punah (critically endangered) dan dalam CITES (2013) termasuk ke dalam daftar apendiks 1 (IUCN, 2013; CITES, 2013).

Pemerintah mengeluarkan Peraturan Pemerintah Nomor 7 Tahun 1999 tentang Pengawetan Jenis Tumbuhan dan Satwa dan Surat Keputusan Menteri Kehutanan Nomor 350/Kpts-11/1997 tentang penetapan kakatua jambul kuning (Cacatua sulphurea citrinocristata) sebagai satwa yang dilindungi. Peraturan Menteri Lingkungan Hidup dan Kehutanan Nomor 106 P.106/MENLHK/ SETJEN/KUM.1/12/2018 tentang Perubahan Kedua atas Peraturan Menteri Lingkungan Hidup dan Kehutanan Nomor P.20/Menlhk/Setjen/Kum.1/6/2018 tentang Jenis Tumbuhan dan Satwa yang Dilindungi, menegaskan bahwa satwa jenis ini termasuk dilindungi. Pemerintah daerah juga mengeluarkan beberapa peraturan, antara lain yaitu Instruksi Gubernur Kepala Daerah Tingkat I Nusa Tenggara Timur Nomor 15 Tahun 1994 tentang Pelarangan Penangkapan semua Jenis Burung di Nusa Tenggara Timur, Keputusan Bupati Sumba Timur Nomor 147 Tahun 1992 dan Keputusan Bupati Sumba Barat Nomor 21 Tahun 1993. Perburuan liar dan degradasi habitat telah menjadi penyebab utama penurunan populasi kakatua di alam. Kakatua memiliki ketergantungan yang tinggi terhadap hutan berkanopi rapat (hutan primer), khususnya yang berada di daratan rendah (terutama di dasar lembah), meskipun sesekali mengunjungi daerah terbuka (Jones, Linsley, \& Marsden, 1995) dan daratan tinggi seperti di Gunung Wanggameti (Hidayat \& Kayat, 2015). Jones et al. (1995) memperkirakan populasinya sekitar 3.200 ekor untuk keseluruhan Pulau Sumba. Mereka bertahan hidup secara berkelompok dalam jumlah yang kecil di beberapa kawasan hutan yang tersisa dan terfragmentasi.

Galla (2006) menemukan sebanyak 25 ekor di Blok Hutan Manurara, 21 ekor di Waimanu dan 11 ekor di Umbu Langgang, pada Blok Hutan Manupeu Tanadaru. Berdasarkan survei yang dilakukan Burung Indonesia pada tahun 2007 populasi kakatua sumba di Taman Nasional Matalawa diperkirakan sebanyak 56 ekor, dengan kepadatan 1,2 individu per 1.000 ha atau 0,012 individu/ha (Wungo, 2011). Survei pada tahun 2011 di Blok Hutan Laiwangi Wanggameti, Taman Nasional Manupeu Tanadaru dan Laiwangi Wanggameti (Matalawa) ditemukan sebanyak 30 individu kakatua sumba (Kayat \& Hidayat, 2011). Berdasarkan data terbaru yang dikeluarkan oleh Balai Taman Nasional Matalawa, populasi kakatua sumba di kawasan tersebut sebanyak 154 ekor (Balai Taman Nasional Matalawa, 2019).

Dalam rangka meningkatkan perlindungan terhadap kakatua kecil jambul kuning, maka disusunlah dokumen Rencana Pemulihan Spesies Kakatua kecil jambul kuning yang diterbitkan oleh (PHPA) Departemen Kehutanan dan Perkebunan, LIPI dan BirdLife International - Indonesian Program pada tahun 1998. Salah satu langkah yang dibutuhkan adalah kegiatan penelitian tentang kebutuhan ekologis. Informasiinformasi penting yang berkaitan dengan ekologi kakatua kecil jambul kuning sampai saat ini masih kurang, sehingga perlu dilakukan penelitian sebagai informasi dasar dalam menentukan upaya konservasi (PHPA/LIPI/ BirdLife International-IP, 1998). Pengetahuan ekologi kakatua yang komprehensif dibutuhkan sebagai panduan dalam kegiatan manajemen spesies dan konservasi (BirdLife International, 2014), sehingga langkah-langkah pengelolaan spesies dan habitat dapat didasari pada hasil riset dan sesuai dengan kondisi ekologi saat ini. 
Salah satu aspek penting terkait kakatua sumba dan belum banyak diketahui adalah preferensi habitat. Informasi ini sangat diperlukan dalam merumuskan manajemen habitat dan membantu konservasionis dalam menentukan wilayah prioritas untuk pelaksanaan pelestarian (Kong et al., 2018). Tidak banyak informasi yang mengungkap preferensi habitat burung kakatua di Indonesia, salah satunya adalah kakatua maluku (Cacatua moluccensis) yang dinyatakan menyukai wilayah dataran rendah (Marsden, 1992).

Tujuan penelitian ini adalah untuk mengetahui preferensi habitat yang dapat digunakan dalam penentuan strategi konservasi in situ kakatua sumba di Taman Nasional Matalawa. Penelitian ini dapat bermanfaat sebagai acuan bagi pengelola kawasan dalam menentukan strategi konservasi in situ melalui pembinaan habitat dengan menggunakan pendekatan preferensi habitat.

\section{BAHAN DAN METODE}

\section{A. Waktu dan Lokasi Penelitian}

Penelitian dilaksanakan pada bulan Juni, November dan Desember di empat blok hutan yaitu Praimahala, Watumbelar, Kokur dan Manurara, Taman Nasional Matalawa (Gambar 1).

Kawasan Taman Nasional Matalawa secara geografis terletak di 9०53' 32,013', - 9॰29' 43,809''LS, $119^{\circ} 26^{\prime}$ 5,64' - 11953'21,172'’BT untuk kelompok hutan Laiwangi Wanggameti, sedangkan kelompok hutan Laiwangi Wanggameti berada pada $120^{\circ} 03^{\prime}-120^{\circ} 19^{\prime}$ BT dan $9^{\circ} 57^{\prime}-10^{\circ} 11^{\prime}$ LS. Ketinggian lokasi antara $0-918$ mdpl, berada di dalam wilayah tiga kabupaten yaitu Sumba Barat, Sumba Tengah dan Sumba Timur, Provinsi Nusa Tenggara Timur. Kawasan Taman Nasional Matalawa tersusun dari kelompok Tanah Daru-Praimamongutidas (RTK 44), kelompok hutan Manupeu (RTK 5) dan kelompok hutan Laiwangi Wanggameti (RTK 50). Bentang alam kawasan Taman Nasional Matalawa didominasi bentukan lahan tipe undulating (perbukitan) dengan persebaran merata di keseluruhan kawasan (Balai Taman Nasional Matalawa, 2018).

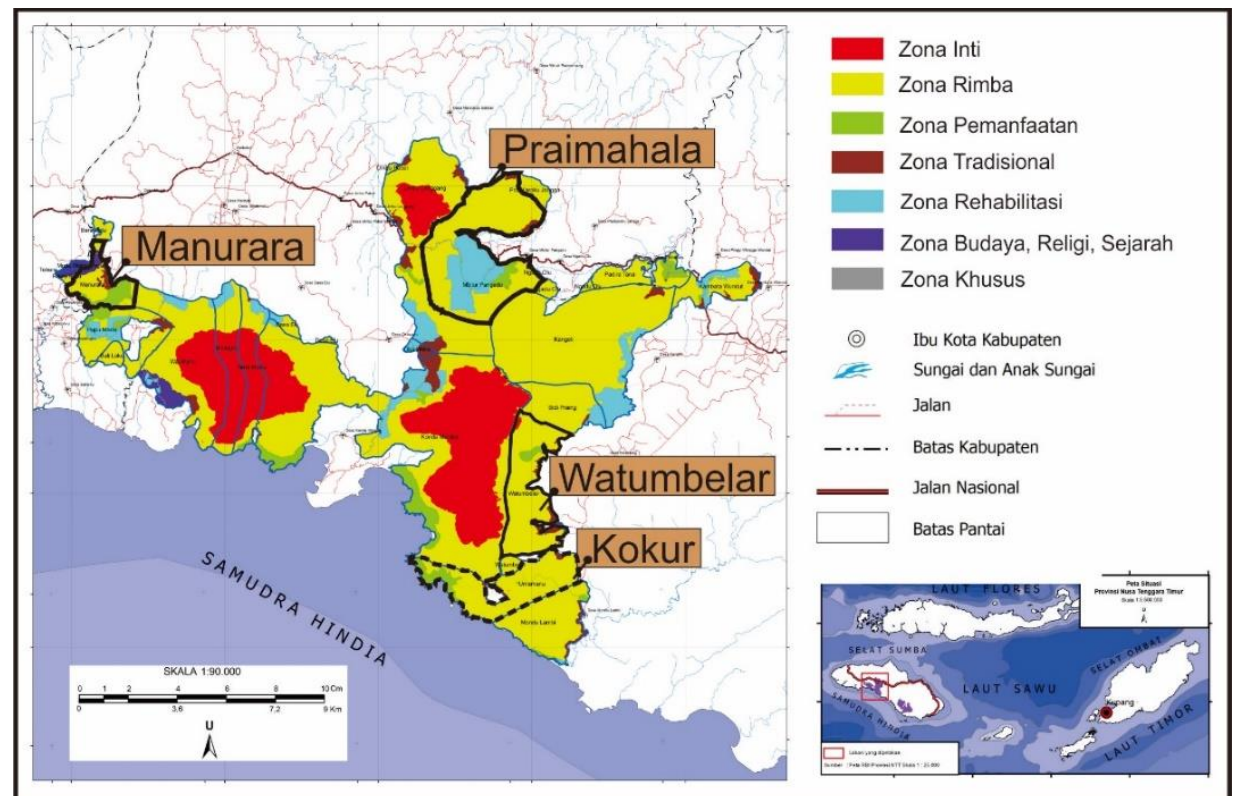

Gambar (Figure) 1. Lokasi penelitian di Taman Nasional Matalawa (Research location at Matalawa National Park) 


\section{B. Pengumpulan Data}

Penelitian ini dilakukan dengan survei secara langsung terhadap habitat dan pengamatan aktivitas kakatua sumba. Sebelum dilakukan pengamatan terlebih dahulu dilakukan penjelajahan untuk mengetahui keberadaan kakatua sumba dengan metode look and see (Bibby, Jones, \& Marsden, 2000). Survei dilakukan dengan berjalan kaki pada lokasi pasti yang telah teridentifikasi sebagai wilayah jelajah kakatua sumba (Hidayat, 2013). Data yang dikumpulkan berupa: frekuensi kehadiran selama dua puluh satu hari pengamatan, aktivitas harian; komponen fisik habitat (ketinggian tempat dan kelerengan); dan komponen biotik habitat (jenis pohon tengger, sarang dan pakan). Untuk mengetahui jenis-jenis pakan kakatua sumba dilakukan pengamatan secara langsung dan wawancara dengan metode Indepthinterview. Responden yang dijadikan narasumber di tiap blok hutan terdiri dari dua orang masyarakat yang telah berpengalaman sebagai pengenal jenis pohon dan penelitian burung sebelumnya.

\section{Analisis Data}

Pendekatan uji Chi-square ( $\chi^{2}$ hit) digunakan untuk mengetahui hubungan antara frekuensi kehadiran satwa dengan habitatnya dengan persamaan sebagai berikut (Rahmat, Santosa, \& Kartono, 2008).

$$
x^{2}{ }_{h i t}=\sum \frac{(O-E)^{2}}{E}
$$

Keterangan (Remarks):

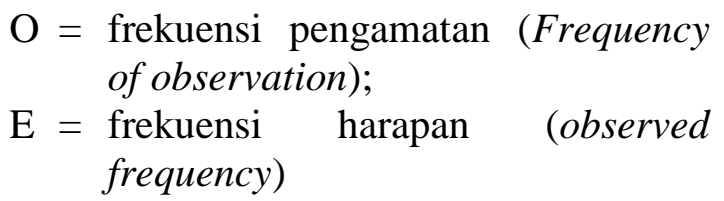

Hipotesis yang dibangun adalah: Ho = semua habitat digunakan dalam proporsi ketersediaannya (tidak ada seleksi); H1 = tidak semua habitat digunakan dalam proporsi ketersediaannya (ada seleksi).
Selanjutnya keputusan yang diambil adalah sebagai berikut : (1) Jika $\chi_{\text {hit }}^{2}>\chi^{2}$ $(0.05, \mathrm{k}-1)$, maka tolak Ho artinya terdapat pemilihan/seleksi habitat ; (2) Jika $\chi^{2}$ hit $\leq$ $\chi^{2}(0.05, \mathrm{k}-1)$, maka terima Ho artinya tidak terdapat pemilihan/seleksi habitat.

Apabila keputusan yang diambil terima Ho maka dilakukan analisis preferensi habitat dengan pendekatan metode $\mathrm{Neu}$. Metode ini merupakan salah satu cara yang biasa digunakan untuk menentukan indeks preferensi habitat oleh satwa (Bibby et al., 2000). Dalam metode ini dilakukan penghitungan proporsi luas lokasi tempat dijumpainya kakatua sumba (p), jumlah perjumpaan (frekuensi) kakatua sumba di suatu lokasi (n), proporsi jumlah perjumpaan kakatua sumba (u), nilai harapan (e), indeks preferensi habitat (w) dan indeks preferensi yang distandarkan (b). Persamaan yang digunakan pada indeks preferensi habitat yaitu : $\mathrm{w}=\mathrm{u} / \mathrm{p}$. Jika nilai indeks preferensi lebih dari satu $(\mathrm{w}>1)$ maka habitat tersebut disukai, sebaliknya jika $w<1$ maka habitat tersebut akan dihindari (Rahmat et al., 2008).

Analisis preferensi komponen biotik pohon tengger dilakukan dengan penghitungan proporsi jumlah pohon tengger yang distandarkan (a), frekuensi kehadiran kakatua pada pohon tengger (n) dan proporsi frekuensi kehadiran kakatua pada pohon tengger (r). Persamaan yang digunakan pada indeks preferensi pohon tengger yaitu : $w=$ r/a. Jika nilai $w>1$ maka pohon tersebut disukai. Data dan informasi hasil wawancara disajikan secara deskriptif.

\section{HASIL DAN PEMBAHASAN}

\section{A. Preferensi terhadap komponen fisik habitat (ketinggian dan kelerengan)}

Berdasarkan hasil uji terhadap komponen habitat ketinggian diketahui bahwa nilai $\chi^{2}{ }_{\text {hit }}>\chi_{(0.05,4)}^{2}$, yaitu 34,09> 14,86. Hal tersebut menunjukkan adanya pemilihan ketinggian tempat oleh kakatua sumba (Tabel 1). 
Tabel (Table) 1. Nilai chi-square pemilihan ketinggian lokasi oleh kakatua sumba ( Chisquare's value of altitude selection by the Sumba Cockatoos)

\begin{tabular}{|c|c|c|c|c|c|c|c|}
\hline $\begin{array}{c}\text { Kelas ketinggian } \\
\text { (Altitude range), } \\
\text { (mdpl) }\end{array}$ & $\mathrm{a}$ & $\mathrm{p}$ & $\mathrm{n}_{\mathrm{i}}=\mathrm{O}_{\mathrm{i}}$ & $\begin{array}{c}e_{\mathrm{i}}=X \\
n_{\mathrm{i}} \mathrm{p}_{\mathrm{i}}\end{array}$ & $\mathrm{O}_{\mathrm{i}}-\mathrm{e}_{\mathrm{i}}$ & $\begin{array}{c}\left(\mathrm{O}_{\mathrm{i}}-\right. \\
\left.\mathrm{E}_{\mathrm{i}}\right)^{2} / \mathrm{E}_{\mathrm{i}}\end{array}$ & $\mathrm{X}^{2}(0.05,4)$ \\
\hline $0-200$ & $10.962,54$ & 0,21 & 0 & 11,71 & $-11,71$ & 11,71 & \\
\hline $201-400$ & $9.154,36$ & 0,18 & 9 & 9,78 & $-0,78$ & 0,06 & \\
\hline $401-600$ & $17.054,28$ & 0,33 & 37 & 18,22 & 18,78 & 19,35 & \\
\hline $601-800$ & $13.342,12$ & 0,26 & 9 & 14,26 & $-5,26$ & 1,94 & \\
\hline $801-1000$ & 960,34 & 0,02 & 0 & 1,03 & $-1,03$ & 1,03 & \\
\hline \multicolumn{2}{|c|}{ Jumlah } & 1 & 55 & 55 & 0,00 & 34,09 & 14,86 \\
\hline
\end{tabular}

Keterangan (Remarks): $\mathrm{a}=$ luas areal (area), $\mathrm{p}=$ proporsi luas areal (area proportion), $\mathrm{O}_{\mathrm{i}}=$ frekuensi kehadiran kakatua (frequency of cockatoo occurance), $\mathrm{e}_{\mathrm{i}}=$ harapan frekuensi kehadiran kakatua (expectation of the frequency of cockatoo occurrence)

Selanjutnya berdasarkan pengujian dengan metode $\mathrm{Neu}$ diketahui bahwa kakatua sumba lebih menyukai lokasi dengan ketinggian tempat antara 401 600 mdpl (Tabel 2). Berbeda dengan di Kawasan Laiwangi Wanggameti, kakatua sumba lebih menyukai daerah dengan rentang ketinggian $201-400 \mathrm{mdpl}$ di Blok Hutan Billa dan 601 - 800 mdpl di Blok Hutan Praingkareha (Hidayat \& Kayat, 2014b).

Berdasarkan hasil uji terhadap komponen habitat kelerengan, diketahui bahwa nilai nilai $\chi_{\text {hit }}^{2}>\chi^{2}(0.05,6)$, yaitu 49,67>18,55 hal tersebut menunjukkan adanya pemilihan kelerengan tempat oleh kakatua sumba (Tabel 3). Berdasarkan hasil penghitungan dengan metode $\mathrm{Neu}$ diketahui bahwa kakatua lebih menyukai daerah-daerah yang terjal (kelerengan 41 $-55 \%)$, landai $(3-8 \%)$ dan sangat terjal (> $55 \%$ ) (Tabel 4). Kehadiran kakatua sumba pada vegetasi yang berada pada rentang ketinggian di atas menunjukkan adanya preferensi terhadap tapak tertentu, sehingga penentuan lokasi prioritas pembinaan habitat sebaiknya dilakukan hanya pada lokasi yang paling disukai saja.

Tabel (Table) 2. Indeks Neu untuk preferensi kakatua sumba berdasarkan ketinggian lokasi (Neu's index for Sumba Cockatoos' preference based on altitude location)

\begin{tabular}{lrlrrrrrr}
\hline $\begin{array}{c}\text { Kelas ketinggian } \\
\text { (Altitude range), } \\
\text { (mdpl) }\end{array}$ & $\begin{array}{c}\mathrm{a} \\
\text { (ha) }\end{array}$ & $\mathrm{p}$ & $\mathrm{n}$ & $\mathrm{u}$ & $\mathrm{e}$ & $\mathrm{w}$ & $\mathrm{b}$ & $\begin{array}{c}\text { Rangking } \\
\text { (Rank) }\end{array}$ \\
\hline $0-200$ & $10.962,54$ & 0,21 & 0 & 0 & 11,71 & 0 & 0 & 4 \\
$201-400$ & $9.154,36$ & 0,18 & 9 & 0,164 & 9,78 & 0,92 & 0,26 & 2 \\
$401-600$ & $17.054,28$ & 0,33 & 37 & 0,673 & 18,22 & $\mathbf{2 , 0 3}$ & 0,57 & 1 \\
$601-800$ & $13.342,12$ & 0,26 & 9 & 0,164 & 14,26 & 0,63 & 0,18 & 3 \\
$801-1000$ & 960,34 & 0.02 & 0 & 0 & 1,03 & 0 & 0 & 4 \\
\hline & & 1 & 55 & 1 & 55 & 3,58 & 1 & \\
\hline
\end{tabular}

Keterangan (Remarks): $\mathrm{p}=$ proporsi luas (area proportion), $\mathrm{n}=$ frekuensi kehadiran kakatua (frequency of cockatoo occurance), $\mathrm{u}=$ proporsi frekuensi kehadiran kakatua (proportion of frequency of cockatoo occurance), $\mathrm{e}=$ nilai harapan (expected value), $\mathrm{w}=$ indeks preferensi (preference index), $\mathrm{b}=$ indeks preferensi yang distrandarkan (standardized of preference index) 
Tabel (Table) 3. Nilai chi-square pemilihan kelerengan tempat oleh kakatua sumba (Chisquare's value of slope selection by the Sumba Cockatoos)

\begin{tabular}{|c|c|c|c|c|c|c|c|}
\hline $\begin{array}{c}\text { Kelerengan tempat } \\
\text { (The location slope), }(\%)\end{array}$ & $\begin{array}{c}\mathrm{a} \\
\text { (ha) }\end{array}$ & $\mathrm{p}$ & $\begin{array}{c}\mathrm{n}_{\mathrm{i}}=\mathrm{O} \\
\mathrm{i}\end{array}$ & $\begin{array}{c}\mathrm{e}_{\mathrm{i}}=\mathrm{X} \\
\mathrm{n}_{\mathrm{i}} \mathrm{p}_{\mathrm{i}}\end{array}$ & $\mathrm{O}_{\mathrm{i}}-\mathrm{E}_{\mathrm{i}}$ & $\begin{array}{c}\left(\mathrm{O}_{\mathrm{i}}-\right. \\
\left.\mathrm{E}_{\mathrm{i}}\right)^{2} / \mathrm{E}_{\mathrm{i}}\end{array}$ & $\mathrm{X}_{(0.05,6)}^{2}$ \\
\hline $0-2$ (datar) (flat) & 581,14 & 0,01 & 0 & 0,62 & $-0,62$ & 0,62 & \\
\hline $3-8$ (landai) (ramps) & $4.588,61$ & 0,09 & 7 & 4,90 & 2,10 & 0,90 & \\
\hline $9-16$ (miring) (sloping) & $9.892,51$ & 0,19 & 2 & 10,57 & $-8,57$ & 6,95 & \\
\hline $17-25$ (curam) (rather steep) & $11.563,92$ & 0,22 & 7 & 12,36 & $-5,36$ & 2,32 & \\
\hline $\begin{array}{l}26-40 \text { (agak terjal) (medium } \\
\text { steep) }\end{array}$ & $14.146,70$ & 0,27 & 10 & 15,12 & $-5,12$ & 1,73 & \\
\hline $\begin{array}{l}41-55(\text { terjal }) \\
(\text { steep })\end{array}$ & $6.548,99$ & 0,13 & 23 & 7,00 & 16,00 & 36,59 & \\
\hline $\begin{array}{l}>55 \text { (sangat terjal) } \\
\text { (very steep) }\end{array}$ & $4.151,77$ & 0,08 & 6 & 4,44 & 1,56 & 0.55 & \\
\hline Jumlah & & 1 & 55 & 55,00 & 0,00 & 49,67 & 18,55 \\
\hline
\end{tabular}

Keterangan (Remarks): $\mathrm{a}=$ luas areal (area), $\mathrm{p}=$ proporsi luas areal (area proportion), $\mathrm{O}_{\mathrm{i}}=$ frekuensi kehadiran kakatua (frequency of cockatoo occurance), $\mathrm{e}_{\mathrm{i}}=$ harapan frekuensi kehadiran kakatua (expectation of the frequency of cockatoo occurrence)

Tabel (Table) 4. Indeks Neu untuk preferensi kakatua sumba berdasarkan kelerengan tempat (Neu's index for Sumba Cockatoos' preference based on location slope)

\begin{tabular}{|c|c|c|c|c|c|c|c|c|}
\hline $\begin{array}{c}\text { Kelerengan tempat } \\
\text { (The location slope }),(\%)\end{array}$ & $\begin{array}{c}\mathrm{a} \\
\text { (ha) }\end{array}$ & $\mathrm{p}$ & $\mathrm{n}$ & $\mathrm{u}$ & e & $\mathrm{W}$ & $\mathrm{b}$ & $\begin{array}{c}\text { Rangking } \\
\text { (Rank) }\end{array}$ \\
\hline $0-2$ (datar) (flat) & 581,14 & 0,01 & 0 & 0,00 & 0,62 & 0,00 & 0,00 & 7 \\
\hline $3-8$ (landai) (ramps) & $4.588,61$ & 0,09 & 7 & 0,13 & 4,90 & 1,43 & 0,19 & 2 \\
\hline $9-16$ (miring) (sloping) & $9.892,51$ & 0,19 & 2 & 0,04 & 10,57 & 0,19 & 0,03 & 6 \\
\hline $17-25$ (curam) (rather & $11.563,92$ & & & & & & & \\
\hline steep) & & 0,22 & 7 & 0,13 & 12,36 & 0,57 & 0,08 & 5 \\
\hline $\begin{array}{l}26-40 \text { (agak terjal) } \\
\text { (medium steep) }\end{array}$ & $14.146,70$ & 0,27 & 10 & 0,18 & 15,12 & 0,66 & 0,09 & 4 \\
\hline $\begin{array}{l}41-55 \text { (terjal) } \\
(\text { steep })\end{array}$ & $6.548,99$ & 0,13 & 23 & 0,42 & 7,00 & 3,29 & 0,44 & 1 \\
\hline $\begin{array}{l}\text { > } 55 \text { (sangat terjal) } \\
\text { (very steep) }\end{array}$ & $4.151,77$ & 0,08 & 6 & 0,11 & 4,44 & 1,35 & 0,18 & 3 \\
\hline
\end{tabular}

Keterangan (Remarks): $\mathrm{p}=$ proporsi luas (area proportion), $\mathrm{n}=$ frekuensi kehadiran kakatua (frequency of cockatoo occurance), $\mathrm{u}=$ proporsi frekuensi kehadiran kakatua (proportion of frequency of cockatoo occurance), $\mathrm{e}=$ nilai harapan (expected value), $\mathrm{w}=\mathrm{indeks}$ preferensi (preference index), $\mathrm{b}=$ indeks preferensi yang distrandarkan (standardized of preference index)

Di Taman Nasional Matalawa terdapat satu wilayah yang teridentifikasi sebagai wilayah jelajah kakatua sumba yaitu di Blok Hutan Mondulambi dengan ketinggian 50 - 100 mdpl namun hanya dua kali kakatua mengunjungi daerah tersebut sehingga dikategorikan sebagai wilayah yang preferensinya sangat rendah (Hidayat \& Kayat, 2014a).

\section{B. Preferensi terhadap komponen biotik habitat (pohon tengger, sarang dan pakan)}

Berdasarkan hasil analisis dengan metode $\mathrm{Neu}$ diketahui pohon tengger yang paling disukai kakatua sumba yaitu halai (Alstonia spectabilis) dan mara (Tetrameles nudiflora) dengan nilai 
indeks preferensi sebesar 2,53 dan 1,87. Tiga pohon tengger lainnya menunjukkan nilai indeks preferensi yang kecil dan jauh dari nilai indeks prefeensi pohon yang disukai (Tabel 5).

Pada saat penelitian ini, sarang aktif kakatua tidak ditemukan sehingga analisis $\mathrm{Neu}$ tidak dapat dilakukan. Preferensi kakatua terhadap pohon sarang diketahui melalui hasil wawancara dengan responden yang menyebutkan bahwa $60 \%$ kakatua sumba memanfaatkan pohon mara ( $T$. nudiflora) sebagai pohon sarang. Hal tersebut menguatkan hasil penelitian Marsden \& Jones (1997) yang menyatakan bahwa pohon tersebut merupakan pohon yang sangat disukai sebagai tempat bersarang. Walker, Cahill, \& Marsden (2005) menyebutkan bahwa nggoka (Chinocheton sp.) merupakan urutan pertama jenis pohon yang paling banyak digunakan sebagai tempat bersarang diikuti oleh pohon mara. Semua jenis kakatua termasuk kakatua sumba menggunakan lubang pohon sebagai tempat bersarang (Cameron, 2007). Selain jenis mara, pohon sarang di Taman Nasional Matalawa umumnya jenis mosa/ kahambi omang (Pometia tomentosa), manera (Aglaia ensiderexylon) dan kaduru (Palaquium sp). Namun survei di tahun 2013 menunjukkan terdapat tiga jenis pohon tidak umum digunakan sebagai tempat bersarang, yaitu Melingtonia hortensi, Glichidion sp., dan Sizygium sp. (Bashari, 2013).

\section{Preferensi terhadap lokasi blok hutan}

Dari hasil penghitungan terhadap frekuensi kehadiran kakatua sumba di tiap blok hutan diketahui bahwa nilai $\chi^{2}$ hit $>\chi^{2}$ $(0.05,3)$, yaitu $14,74>12,84$ hal tersebut menunjukkan adanya pemilihan lokasi oleh kakatua sumba (Tabel 6). Berdasarkan analisis dengan metode $\mathrm{Neu}$ dapat diketahui bahwa kakatua paling menyukai Blok Hutan Kokur (Tabel 7).

Tabel (Table) 5. Preferensi pohon tengger kakatua sumba (The roosting tree preference of the Sumba Cockatoos)

\begin{tabular}{llrrrrrc}
\hline $\begin{array}{c}\text { Jenis Pohon } \\
\text { (Tree species) }\end{array}$ & \multicolumn{1}{c}{$\begin{array}{c}\text { Nama Latin } \\
\text { (Scientific name) }\end{array}$} & $\mathrm{a}$ & $\mathrm{n}$ & $\mathrm{r}$ & $\mathrm{w}$ & $\mathrm{b}$ & $\begin{array}{c}\text { Rangking } \\
\text { (Rank) }\end{array}$ \\
\hline Halai & Alstonia spectabilis & 16,67 & 19 & 42,22 & $\mathbf{2 , 5 3}$ & 0,42 & 1 \\
Mara & Tetrameles nudiflora & 16,67 & 14 & 31,11 & $\mathbf{1 , 8 7}$ & 0,31 & 2 \\
Lamo & Melia azedarach & 16,67 & 4 & 8,89 & 0,53 & 0,09 & 3 \\
Hurani & Toona sureni & 16,67 & 3 & 6,67 & 0,40 & 0,07 & 4 \\
Mosa & Pometia tomentosa & 16,67 & 3 & 6,67 & 0,40 & 0,07 & 4 \\
Kaduru & Palaquium sp. & 16,67 & 2 & 4,44 & 0,27 & 0,04 & 5 \\
\hline & Jumlah & 100 & 45 & 100 & 6 & 1 & \\
\hline
\end{tabular}

Keterangan (Remarks): a=proporsi jumlah pohon tengger yang distandarkan (proportion of total roosing tree species), $\mathrm{n}=$ frekuensi kehadiran kakatua pada pohon tengger (frequency of cockatoo occurance on roosting tree), $\mathrm{r}=$ proporsi frekuensi kehadiran kakatua pada pohon tengger (proportion of frequency of cockatoo occurance on roosting tree ), $\mathrm{w}=$ indeks preferensi (preference index), $\mathrm{b}=$ indeks preferensi yang distrandarkan (standardized of preference index) 


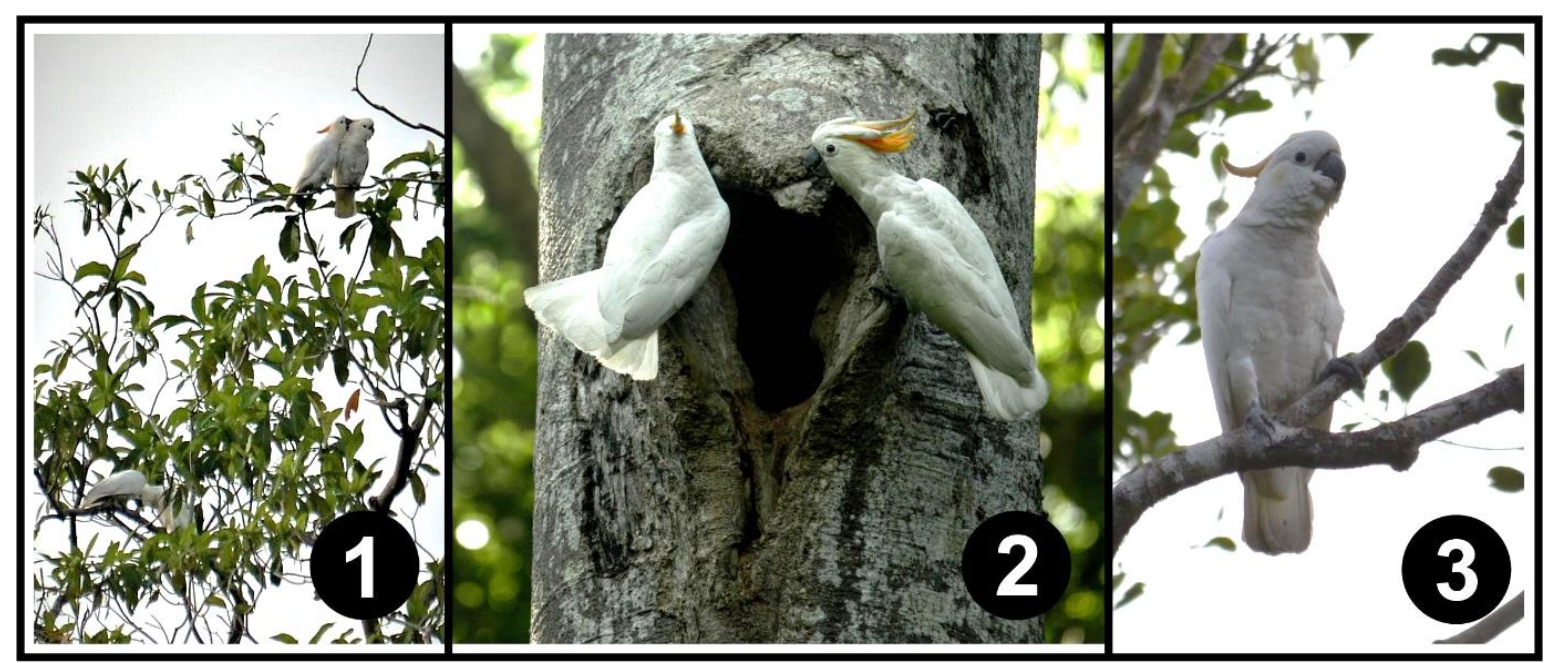

Gambar(Figure) 2. (1) Aktivitas bercumbu/saling menelisik di Pohon Halai (Courtship activity/caressing at Halai Tree); (2) Aktivitas beristirahat di Pohon Mara (Rest activity at Mara Tree); (3) Aktivitas makan di Pohon Kapuk Hutan (Feeding activity at Kapuk Tree)

Tabel (Table) 6. Nilai chi-square pemilihan habitat oleh kakatua sumba (Chi-square's value of habitat selection by the Sumba Cockatoos)

\begin{tabular}{|c|c|c|c|c|c|c|c|}
\hline $\begin{array}{c}\text { Lokasi } \\
\text { (location) }\end{array}$ & $\begin{array}{c}\mathrm{A} \\
\left(\mathrm{km}^{2}\right)\end{array}$ & $\mathrm{p}$ & $\mathrm{n}_{\mathrm{i}}=\mathrm{O}_{\mathrm{i}}$ & $e_{i}=X n_{i} p_{i}$ & $\mathrm{O}_{\mathrm{i}}-\mathrm{e}_{\mathrm{i}}$ & $\begin{array}{c}\left(\mathrm{O}_{\mathrm{i}}-\right. \\
\left.\mathrm{E}_{\mathrm{i}}\right)^{2} / \mathrm{E}_{\mathrm{i}} \\
\end{array}$ & $\mathrm{X}_{(0,05,3)}^{2}$ \\
\hline Praimahala & $4.880,10$ & 0,439 & 9 & 13,75 & $-4,75$ & 1,64 & \\
\hline Manurara & 1014,93 & 0,091 & 9 & 13,75 & $-4,75$ & 1,64 & \\
\hline Watumbelar & 2711,07 & 0,244 & 11 & 13,75 & $-2,75$ & 0,55 & \\
\hline Kokur & 2511,25 & 0,226 & 26 & 13,75 & 12,25 & 10,91 & \\
\hline Jumlah & 11117,35 & 1 & 55 & 55 & 0,00 & 14,74 & 12,84 \\
\hline
\end{tabular}

Keterangan (Remarks): $\mathrm{a}=$ luas areal pengamatan (area observed), $\mathrm{p}=$ proporsi luas areal (area proportion), $\mathrm{O}_{\mathrm{i}}=$ frekuensi kehadiran kakatua (frequency of cockatoo occurance), $\mathrm{e}_{\mathrm{i}}=$ harapan frekuensi kehadiran kakatua (expectation of the frequency of cockatoo occurance)

Tabel (Table) 7. Indeks Neu untuk preferensi habitat berdasarkan lokasi (Neu's index for habitat preference based on location)

\begin{tabular}{lccrrrrrc}
\hline $\begin{array}{c}\text { Lokasi } \\
(\text { Location })\end{array}$ & $\begin{array}{c}\mathbf{a} \\
\left(\mathbf{k m}^{2}\right)\end{array}$ & $\mathbf{p}$ & $\mathbf{n}$ & $\mathbf{u}$ & $\mathbf{e}$ & $\mathbf{w}$ & $\mathbf{b}$ & $\begin{array}{c}\text { Rangking } \\
(\text { Rank })\end{array}$ \\
\hline Praimahala & $4.880,10$ & 0,439 & 9 & 0,164 & 13,75 & 0,655 & 0,16 & 3 \\
Manurara & $1.014,93$ & 0,091 & 9 & 0,164 & 13,75 & 0,655 & 0,16 & 3 \\
Watumbelar & $2.711,07$ & 0,244 & 11 & 0,20 & 13,75 & 0,80 & 0,2 & 2 \\
Kokur & $2.511,25$ & 0,226 & 26 & 0,473 & 13,75 & $\mathbf{1 , 8 9 1}$ & 0,47 & 1 \\
\hline \multicolumn{1}{c}{ Jumlah } & $11.117,35$ & 1 & 55 & 1 & 55 & 4 & 1 & \\
\hline
\end{tabular}

Keterangan (Remarks): $\mathrm{a}=$ luas plot pengamatan (plot observation area), $\mathrm{p}=$ proporsi luas (area proportion), $\mathrm{n}=$ frekuensi kehadiran kakatua (frequency of cockatoo occurance), $\mathrm{u}=$ proporsi frekuensi kehadiran kakatua (proportion of frequency of cockatoo occurance), e=nilai harapan (expected value), $\mathrm{w}=$ indeks preferensi (preference index), $\mathrm{b}=$ indeks preferensi yang distrandarkan (standardized of preference index) 
Blok Hutan Kokur merupakan lokasi habitat kakatua sumba yang memiliki keanekaragaman jenis tumbuhan tertinggi dibandingkan blok hutan lainnya, dengan nilai indeks keanekaragaman Shannon-wiener sebesar 3,39 (Hidayat \& Kayat, 2014a). Pemilihan lokasi juga dipengaruhi oleh ketersediaan jumlah pakan dan keberadaan predator (Cameron \& Cunningham, 2006). Oleh karena itu kakatua sumba menyukai lokasi tersebut karena terdapat banyak pilihan pohon tengger, sarang dan pakan. Faktor lain yang menyebabkan Blok Hutan Kokur mempunyai preferensi habitat tertinggi adalah adanya pohon tidur. Dari keempat lokasi penelitian hanya Blok Hutan Kokur yang memiliki pohon untuk tidur. Kakatua sumba dan beberapa burung paruh bengkok lainnya seperti etet-kelapa paruhbesar (Tanygnathus megalorinchos) dan nuri bayan (Ecletus rotatus) memanfaatkan pohon nggoka (Chinocheton sp.) dan kaduru (Palaquium sp.) sebagai pohon tidur. Pada Blok Hutan Kokur terdapat kebun palawija milik masyarakat di pinggir kawasan yang menyebabkan tingkat kehadiran kakatua sumba dan burung paruh bengkok lainnya di lokasi ini cukup tinggi. Menurut Warsito \& Bismark (2010), burung paruh bengkok suka mendatangi kebun palawija untuk mencari makan pada saat musim panen tiba.

\section{Strategi in in situ}

Konservasi in situ merupakan salah satu langkah manajemen spesies di habitat alaminya yang umum dilakukan serta lebih bermanfaat terhadap spesies dan ekosistem (Greenwood, 1996; Watson, 2014). Langkah ini cocok untuk spesies yang sensitif terhadap gangguan atau kehadiran manusia secara langsung (Bell \& Merton, 2002). Jika diterapkan untuk kakatua sumba langkah tersebut sesuai, mengingat tingginya tingkat sensitivitas terhadap kontak langsung dengan manusia. Terdapat banyak cara dalam mengaplikasikan teknik konservasi in situ, salah satu yang telah umum dilakukan di Indonesia adalah dengan pembinaan/manajemen habitat. Bell \& Merton (2002) menyebutkan beberapa teknik manajemen untuk burung terancam punah dengan kategori kritis (critically endangered) dapat diterapkan melalui manejemen habitat, sarang, tempat berlindung (shelter) dan pakan.

Langkah-langkah konservasi in situ kakatua sumba sebaiknya memperhatikan faktor-faktor yang membuat kakatua menyukai suatu lokasi. Upaya manajemen habitat di Taman Nasional Matalawa sebaiknya dilakukan melalui tiga tahapan, yaitu tahapan jangka pendek, menengah dan panjang. Setiap tahapan memiliki jangkauan waktu pengaruh yang berbeda. Langkah-langkah tersebut tersaji pada Tabel 8.

Tabel (Table) 8. Strategi konservasi in-situ melalui pembinaan habitat (In-situ conservation strategies through habitat management)

\begin{tabular}{|c|c|c|}
\hline $\begin{array}{c}\text { Jangka Pendek } \\
\text { (short term) }\end{array}$ & $\begin{array}{l}\text { Jangka Menengah } \\
\text { (middle term) }\end{array}$ & $\begin{array}{c}\text { Jangka Panjang } \\
(\text { long term })\end{array}$ \\
\hline $\begin{array}{l}\text { Pengamanan terhadap pohon } \\
\text { sarang dari ancaman alam dan } \\
\text { manusia (Safeguarding nest trees } \\
\text { from natural and human threats) }\end{array}$ & $\begin{array}{l}\text { Pembersihan ara pencekik dan } \\
\text { liana pada pohon penting bagi } \\
\text { kakatua (Cleaning strangler figs } \\
\text { and lianas on trees that are } \\
\text { important to cockatoos) }\end{array}$ & $\begin{array}{l}\text { Pengayaan tumbuhan penting } \\
\text { bagi kakatua melalui penanaman } \\
\text { anakan pohon (Enrichment of } \\
\text { essential plants for cockatoos by } \\
\text { planting saplings) }\end{array}$ \\
\hline
\end{tabular}


Upaya jangka pendek akan terlihat implikasinya dalam waktu yang relatif dekat. Pengamanan pohon sarang penting dilakukan sebagai upaya mempertahankan keberadaan pohon sarang yang terbatas, terlebih lagi untuk pohon sarang yang diketahui aktif atau pernah aktif sebelumnya. Beberapa contoh kasus seperti yang terjadi di Kawasan Laiwangi Wanggameti menunjukkan adanya ancaman terhadap pohon sarang di antaranya tumbangnya pohon akibat alam maupun manusia (Hidayat \& Kayat, 2012). Contoh ancaman alam adalah keberadaan pepohonan yang rapuh di sekitar pohon sarang. Pohon-pohon tersebut akan roboh dengan sendirinya terutama pada saat musim angin dan hujan tiba. Jika pohon tersebut roboh dan menimpa pohon sarang maka dapat dipastikan pohon sarang akan terganggu bahkan dapat ikut roboh. Selain ancaman alam, ancaman manusia juga perlu diwaspadai, contoh kasus di TNLW adanya pohon sarang berjenis mara $(T$. nudiflora) yang dibakar oleh oknum masyarakat pada bagian pangkal pohon, meskipun tidak sampai membakar batang, bagian banir dan pangkal batang menjadi berlubang (Kayat \& Hidayat, 2011). Kondisi tersebut jelas membuat kekokohan pohon tersebut berkurang dan berpotensi tumbang.

Contoh-contoh di atas perlu dijadikan sebagai salah satu bahan pertimbangan penentuan manajemen habitat yang berimplikasi pada besarnya perhatian terhadap pengamanan komponen habitat terutama pohon pakan, sarang dan tengger. Pengamanan kawasan perlu dilakukan dengan lebih intensif lagi karena ancaman terhadap kerusakan habitat kakatua sumba di Taman Nasional Matalawa masih cukup tinggi. Hal tersebut dibuktikan dengan ditemukannya secara langsung kegiatan penebangan pohon berdiameter besar $(>40 \mathrm{~cm})$ pada habitat utama kakatua sumba tepatnya di wilayah Blok Hutan Manurara (Hidayat \& Kayat, 2014a). Jika tekanan kawasan tersebut terus berlangsung maka akan mengakibatkan degradasi habitat. Kemudian kerusakan habitat akan berkembang menjadi degradasi keanekaragaman hayati yang jika dibiarkan berlanjut terus akan mengancam keutuhan potensi kawasan (Putri \& Allo, 2009). Melihat kondisi tersebut maka frekuensi pengamanan kawasan sebaiknya lebih tinggi pada zona rimba dan zona pemanfaatan.

Upaya jangka menengah dampak manajemen habitat terlihat dalam waktu yang sedikit lebih lama dari jangka pendek, kemungkinan sekitar $10-15$ tahun. Upaya jangka menengah ini lebih dikhususkan untuk vegetasi tingkat belta (pohon muda). Salah satu ciri hutan tropis adalah adanya liana dan tumbuhan ara pencekik, jenis Ficus spp. (strangler fig). Keberadaan liana dan strangler fig jika dibiarkan akan menggangu pohon sarang bahkan dapat menyebabkan kematian jika strangler fig sudah mengelilingi penuh pohon inang dan masuk ke dalam pembuluh xylem. Cara pemberantasannya adalah dengan memotong pada pangkal batang liana/strangler fig. Cara serupa pernah dilakukan di kawasan hutan Laiwangi Wanggameti untuk menyelamatkan pohon sarang (Hidayat \& Kayat, 2012).

Langkah jangka panjang yang terdapat di Tabel 8 merupakan strategi yang umum dilakukan. Namun yang perlu menjadi perhatian adalah kesesuaian lokasi penanaman anakan yang harus mengacu pada komponen habitat yang disukai oleh kakatua sumba di kawasan Manupeu Tanadaru. Penanaman sebaiknya dilakukan pada lahan yang memiliki rentang ketinggian 401 - 600 mdpl serta pada daerah yang memiliki kelerengan terjal $(41-55 \%)$. Tujuan pengelolaan satwa liar terletak pada konservasi habitat, membebaskannya dari gangguan dan mengusahakan agar vegetasi alaminya tetap terjaga dan utuh. Jika hal tersebut tidak dilakukan maka populasi satwa dapat terganggu dan akan 
lebih sulit lagi untuk mengelolanya (Soewardi, 1978).

Kegiatan pengelolaan habitat satwa liar merupakan proses yang dinamis, fluktuasi keberhasilannya harus terpantau sehingga dapat dilakukan evaluasi untuk penyempurnaannya (Alikodra, 2010). Riset dan percobaan di lapangan sangat diperlukan untuk mendapatkan strategi manajemen habitat yang optimal (Indrawan, Primack, \& Supriatna, 2007). Berdasarkan hasil penelitian ini diketahui jenis-jenis tumbuhan yang penting dalam menunjang kehidupan kakatua sumba (Tabel 9). Selanjutnya dalam penyusunan kegiatan pengayaan vegetasi sebaiknya jenis-jenis tersebut dijadikan prioritas dan ditanam pada lokasi yang sesuai. Kegiatan pengumpulan biji perlu dilakukan secara rutin untuk membangun persemaian pohon-pohon penting bagi kakatua sumba. Jenis-jenis tersebut kemudian dapat juga ditanam pada kawasan penyangga yang berupa hutan rakyat campuran yang terdiri dari vegetasi alam dan tanaman budidaya masyarakat di sekitar taman nasional. Keberadaan hutan tersebut akan berperan sebagai koridor hijau yang berfungsi sebagai habitat tambahan bagi satwaliar (Kuswanda \& Sukmana, 2009).

Tabel (Table) 9. Jenis-jenis tumbuhan prioritas dalam program pengayaan vegetasi penting bagi kakatua sumba beserta karakteristik tapak penanamannya (Priority plant species in the important vegetation enrichment program for Sumba Cockatoo and the characteristics of their planting sites)

\begin{tabular}{|c|c|}
\hline $\begin{array}{l}\text { Faktor penting } \\
\text { (Essential factors) }\end{array}$ & Jenis (Species) \\
\hline $\begin{array}{l}\text { Tumbuhan pakan (Feeding plant } \\
\text { species) }\end{array}$ & $\begin{array}{l}\text { Lamo* (Melia azedarach), Kananggar* (Dillenea sp.), Andinu } \\
\text { miting* (Melochia umbellate), Mosa (P.tomentosa), Tanggala } \\
\text { (Claoxylon longifolium), Katikataru (Litsea accedentoides), } \\
\text { Kayarak* (Querqus piriformis), Jarik rundu (Citrus sp.), Walakari } \\
\text { (Erythrina sp.), Kepapang* (Phaseolus lunatus), Tadamuru } \\
\text { (Terminalia supitiana), Kaduru (Palaquium obtusifolium), Tambura } \\
\text { (Cleidin javanicum) }\end{array}$ \\
\hline Pohon Sarang(Nesting tree) & $\begin{array}{l}\text { Mara (T.nudiflora), Mosa (P.tomentosa), Nggoka (Chinocheton sp.), } \\
\text { Manera (Aglaia ensiderexylon), Glichidion sp., Sizygium sp. }\end{array}$ \\
\hline $\begin{array}{l}\text { Pohon Istirahat/Pohon tengger } \\
\text { (Resting/roosting tree) }\end{array}$ & $\begin{array}{l}\text { Halai (Alstonia spectabilis), Mara (T.nudiflora), Kaduru (Palaquium } \\
\text { sp.) }\end{array}$ \\
\hline \multicolumn{2}{|c|}{ Karakteristik tapak penanaman (Site planting characteristic) } \\
\hline Prioritas Pertama (First priority) : & $\begin{array}{l}\text { Blok hutan yang kurang disukai kakatua sumba (Forest block that is } \\
\text { less favoured by the Sumba Cocckatoos). Dengan urutan prioritas (In } \\
\text { priority order): (1) Blok Hutan Praimahala/Manurara } \\
\text { (Praimahala/Manurara forest block), (2) Watumbelar, (3) Kokur; } \\
\text { lokasi penanaman pada kelerengan terjal (planting site on steep } \\
\text { slope) }(41-55 \%) \text {, landai (sloping) }(3-8 \%) \text { dan sangat terjal (very } \\
\text { steep) (> } 55 \%) \text {, berada pada ketinggian } 401-600 \text { mdpl (on the } \\
\text { altitude of } 401-600 \text { asl). }\end{array}$ \\
\hline
\end{tabular}

Prioritas kedua (Second priority) : Blok Hutan Kokur (Kokur forest block)

Keterangan (Remarks): tanda asterisk (*) adalah pakan yang disukai, (asterisk symbol $(*)$ as the preferred food) (Hidayat, 2014) 
Indra, Prasetyo, \& Soekmadi (2006) menyatakan bahwa sekitar 52,89 \% dari kawasan hutan Manupeu Tanadaru merupakan daerah berhutan yang tingkat kerentanannya tinggi. Oleh karena itu perlindungan terhadap kualitas kawasan berupa reboisasi harus dilakukan secara simultan untuk mencegah longsor dan menyediakan kebutuhan hidup satwa liar termasuk kakatua sumba. Pada zona pemanfaatan dengan vegetasi yang terganggu, kakatua teramati memanfaatkan tanaman budidaya sebagai sumber pakan. Atas pertimbangan kondisi tersebut kegiatan penghijauan sebaiknya difokuskan pada zona rimba dan zona pemanfaatan.

\section{KESIMPULAN DAN SARAN}

\section{A. Kesimpulan}

Kakatua sumba memiliki preferensi terhadap habitatnya di Taman Nasional Matalawa. Lokasi yang paling disukai adalah daerah dengan ketinggian 401 600 mdpl, kelerengan terjal $(41-55 \%)$, landai $(3-8 \%)$ dan sangat terjal (> $55 \%)$. Lokasi blok hutan yang paling disukai adalah Kokur. Upaya konservasi in situ yang dapat dilakukan antara lain yaitu pengamanan terhadap pohon sarang dari ancaman alam dan manusia, pembersihan ara pencekik dan liana pada pohon penting bagi kakatua, pengayaan tumbuhan penting bagi kakatua melalui penanaman anakan pohon.

\section{B. Saran}

Pengumpulan biji atau cabutan jenis tumbuhan pakan, sarang dan tengger dapat dilakukan bersamaan dengan patroli rutin pengamanan kawasan untuk efisiensi waktu dan biaya. Pembangunan persemaian permanen sebaik-nya dilakukan untuk menyediakan berbagai macam anakan pohon penting bagi kakatua sumba.

\section{UCAPAN TERIMA KASIH}

Ucapan terimakasih disampaikan kepada: 1). Kepala Balai Penelitian Kehutanan Kupang, dan Kepala Balai Taman Nasional Matalawa beserta seluruh staf yang telah memberikan dukungan atas berjalannya penelitian ini, khususnya Luthfi R. Y., Dwi Putro N., Boby Darmawan, Hastoto A., Eka Y., Musa, Sosi, Simon Onggo, Agus Kusumanegara dan Marjono Merrapu. 2). Eko Pujiono, S.Hut, M.Sc yang telah memberikan bimbingan. 3). Melianus Wanaha yang telah membantu kegiatan survei lapangan.

\section{DAFTAR PUSTAKA}

Alikodra, H. S. (2010). Teknik Pengelolaan Satwaliar Dalam Rangka Mempertahankan Keanekaragaman Hayati Indonesia. Bogor: IPB Press.

Bashari, H. (2013). Nesting ecology and strategic natural treatment for the nest of the critically endangered yellowcrested cockatoo Cacatua sulphurea citrinocristata in Sumba. Proceeding International Conference Forest and Biodiversity (hal.479-484).

Bell, B. D., \& Merton, D. V. (2002). Critically endangered bird populations and their management, dalam K. Norris \& D. J. Pain. (Eds.) Conserving bird biodiversity. Cambridge: Cambridge University Press.

Bibby, C., Jones, M., \& Marsden, S. J. (2000). Teknik-teknik ekspedisi lapangan survey burung. Bogor: BirdLife International-Indonesia Programme.

BirdLife International. (2014). Species factsheet: Cacatua sulphurea. Diakses dari http://www.birdlife.org. pada 3 Maret 2014.

Balai Taman Nasional Matalawa. (2018). Statistik Balai TN Matalawa 2018. Waingapu: Balai TN Matalawa. 
Balai Taman Nasional Matalawa. (2019). Monitoring Populasi Kakatua Jambul Jingga dan Julang Sumba Tahun 2019. Waingapu: Balai Taman Nasional Matalawa.

Cameron, M. (2007). Cockatoos. Clayton: CSIRO Publishing.

Cameron, M., \& Cunningham, R. B. (2006). Habitat selection at multiple spatial scales by foraging Glossy Black-cockatoos. Austral Ecology, 31, 597-607.

CITES. (2013). Appendices 1, 2, 3. Diakses dari http://www.cites.org. pada 4 Juli 2013.

Galla, W. Y. (2006). Distribusi dan Aktivitas Kakatua Kecil Jambul Kuning (Cacatua sulphurea citrinocristata Fraser, 1844) di TN Manupeu Tanadaru, Kab. SumbaNTT. (Skripsi Sarjana). Universitas Udayana, Denpasar.

Greenwood, A. G. (1996). Veterinary support for in situ avian conservation programs. Bird Conservation International, 6, 285-292.

Hidayat, O., \& Kayat. (2012) Analisis preferensi habitat kakatua sumba di Taman Nasional Laiwangi Wanggameti. Kupang: Balai Penelitian Kehutanan Kupang.

Hidayat, O. (2013). Status kakatua sumba di Taman Nasional Manupeu Tanadaru. Majalah Kabesak, 16(3), 24-27.

Hidayat, O. (2014). Komposisi jenis, preferensi dan sebaran tumbuhan pakan kakatua sumba (Cacatua sulphurea citrinocristata) di Taman Nasional Laiwangi Wanggameti. Jurnal Penelitian Kehutanan Wallacea, 3(1), 25-36.

Hidayat, O., \& Kayat. (2014a). Habitat Kakatua Sumba (Cacatua sulphurea citrinocristata) dan Ancamannya di Taman Nasional Manupeu Tanadaru. Kupang: Balai Penelitian Kehutanan Kupang.
Hidayat, O., \& Kayat. (2014b) Karakteristik dan preferensi habitat kakatua sumba (Cacatua sulphurea citrinocristata) di Taman Nasional Laiwangi Wanggameti. Jurnal Widyariset, 17(3), 399-408.

Indra S. P., Prasetyo L. B., \& Soekmadi, R. (2006). Penyusunan zonasi Taman Nasional Manupeu Tanadaru, Sumba berdasarkan kerentanan kawasan dan aktifitas masyarakat. Media Konservasi, 11(1), 1-16.

Indrawan, M., Primack, R. B., \& Supriatna, J. (2007). Biologi Konservasi (revisi). Jakarta: Yayasan Obor Indonesia.

IUCN. (2013). The IUCN red list of threatened species. Diakses dari http:// www.iucnredlist.org. pada 4 Juli 2013.

Kayat \& Hidayat, O. (2011). Kajian Pohon Sarang Kakatua Sumba (Cacatua sulphurea citrinocristata) di Taman Nasional Laiwangi Wanggameti. Kupang: Balai Penelitian Kehutanan Kupang.

Kong, D., Luo, W., Liu, Q., Li, Z., Huan, G., Zhang, J., \& Yang, X. (2018). Habitat use, preference, and utilization distribution of two crane species (Genus: Grus) in Huize National Nature Reserve, YunnanGuizhou Plateau, China. PeerJ Life \& Environment, 6(e5105), 1-15. doi: 10.7717/peerj.5105.

Kuswanda, W., \& Sukmana, A. (2009). Kesesuaian jenis untuk pengayaan habitat orangutan terdegradasi di daerah penyangga Cagar Alam Dolok Sibual-Buali. Jurnal Penelitian Hutan dan Konservasi Alam, 6(2), 125-139.

Marsden, S. J. (1992). The distribution, abundance and habitat preferences of the Salmon-crested Cockatoo Cacatua moluccensis on Seram, Indonesia. Bird Conservation International, 2, 7-14. 
Marsden, S. J., \& Jones, M. J. (1997) The nesting requirements of the parrots and hornbill of Sumba, Indonesia. Biological Conservation, 82, 279287.

PHPA/LIPI/BirdLife International-IP. (1998). Rencana Pemulihan Kakatuakecil jambul-kuning. Bogor: PHPA/LIPI/BirdLife InternationalIP.

Putri, I. A. S. L. P., \& Allo, M. K. (2009) Degradasi keanekaragaman hayati Taman Nasional Rawa Aopa Watumohai. Jurnal Penelitian Hutan dan Konservasi Alam, 6(2), 169-194.

Rahmat, U. M., Santosa Y., \& Kartono, A. P. (2008). Analisis preferensi habitat badak jawa di Taman Nasional Ujung Kulon. Jurnal Manajemen Hutan Tropika, 14(3), 115-124.

Soewardi, H. (1978). Menyongsong Kehadiran Taman Nasional di Indonesia. Bogor: Direktorat Perlindungan dan Pengawetan Alam.
Walker J. S., Cahill A. J., \& Marsden, S. J. (2005). Factors influencing nestsite occupancy and low reproductive output in the critically endangered Yellow-crested Cockatoo Cacatua sulphurea on Sumba, Indonesia. Bird Conservation International, 15, 347359.

Warsito, H., \& Bismark, M. (2010). Penyebaran dan populasi burung paruh bengkok pada beberapa tipe habitat di Papua. Jurnal Penelitian Hutan dan Konservasi Alam, 7(1), 93-102.

Watson, D. (2014). Biodiversity and conservation approaches: In situ and ex situ avian conservation. Diakses dari http://scoutingforbirds.com. pada 13 Februari 2014.

Wungo, E. Y. (2011). Laporan survei populasi paruh bengkok terancam punah Cacatua sulphurea citrinocristata, Sumba, Nusa Tenggara Timur. Bogor: Burung Indonesia. 